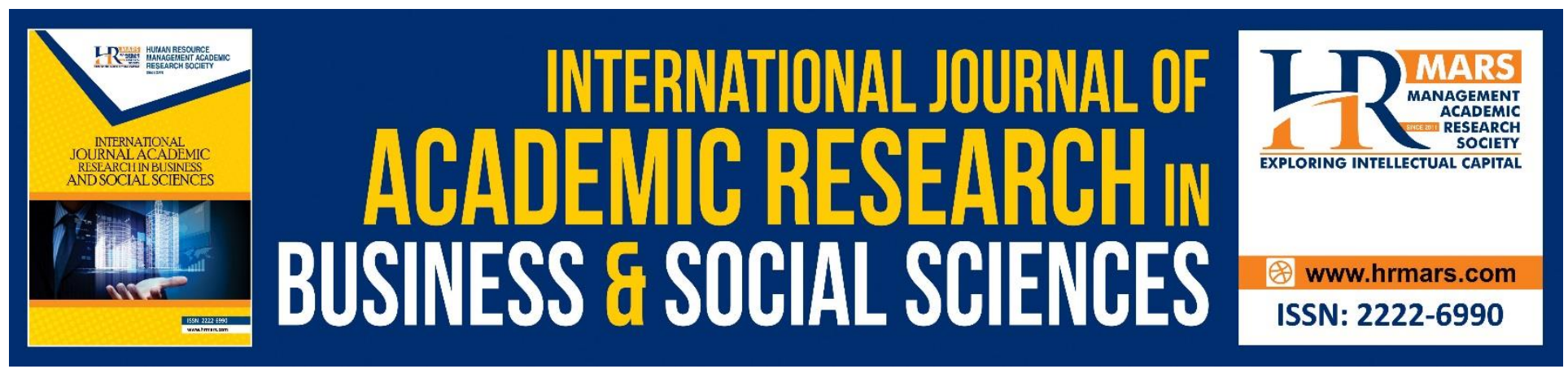

\title{
A Systematic Review on the Mah Meri People in Malaysia
}

\section{Mohd Haikal Zuhairi, Mohd Roslan Rosnon \& Jamilah Shaari}

To Link this Article: http://dx.doi.org/10.6007/IJARBSS/v10-i16/8293

DOI:10.6007/IJARBSS/v10-i16/8293

Received: 07 September 2020, Revised: 10 October 2020, Accepted: 30 October 2020

Published Online: 18 November 2020

In-Text Citation: (Zuhairi et al., 2020)

To Cite this Article: Zuhairi, M. H., Rosnon, M. R., \& Shaari, J. (2020). A Systematic Review on the Mah Meri People in Malaysia. International Journal of Academic Research in Business and Social Sciences, 10(16), 7395.

Copyright: (c) 2020 The Author(s)

Published by Human Resource Management Academic Research Society (www.hrmars.com)

This article is published under the Creative Commons Attribution (CC BY 4.0) license. Anyone may reproduce, distribute, translate and create derivative works of this article (for both commercial and non-commercial purposes), subject to full attribution to the original publication and authors. The full terms of this license may be seen at: http://creativecommons.org/licences/by/4.0/legalcode

Special Issue: Youth and Community Wellbeing: Issues, Challenges and Opportunities for Empowerment V2, 2020, Pg. 73 - 95 http://hrmars.com/index.php/pages/detail/IJARBSS JOURNAL HOMEPAGE

Full Terms \& Conditions of access and use can be found at http://hrmars.com/index.php/pages/detail/publication-ethics 


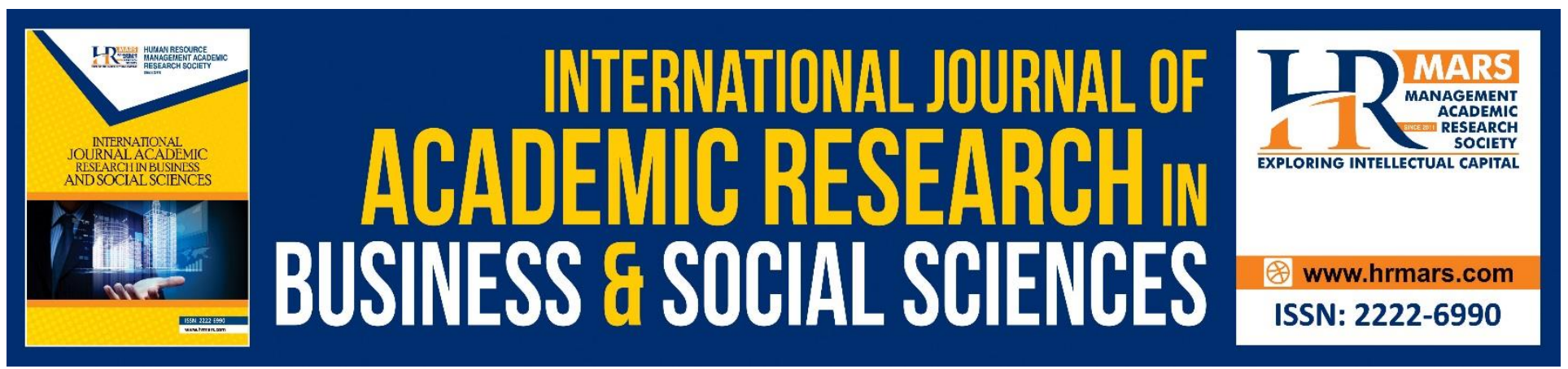

\title{
A Systematic Review on the Mah Meri People in Malaysia
}

\author{
Mohd Haikal Zuhairi, ${ }^{1,2}$, Mohd Roslan Rosnon ${ }^{1,2}$ \& Jamilah Shaari ${ }^{3}$ \\ ${ }^{1}$ Institute for Social Science Studies, Universiti Putra Malaysia, 43400 UPM, Serdang, Selangor, \\ Malaysia, ${ }^{2}$ Department of Social \& Development Sciences, Faculty of Human Ecology, Universiti \\ Putra Malaysia, 43400 UPM, Serdang, Selangor, Malaysia, ${ }^{3}$ School of Health Sciences, Universiti \\ Sains Malaysia, Health Campus, 11800, Gelugor, Pulau Pinang, Malaysia. \\ Email: mohdhaikalz@yahoo.com, roslan_rosnon@upm.edu.my, jamilahshaari@usm.my
}

\begin{abstract}
As an indigenous people of Malaysia, the Orang Asli consists of eighteen (18) different ethnicities throughout the Malaysia peninsular. Ironically, the Orang Asli is still commonly associated with the poor condition of social and economic status, although this diversity reflects the variety and richness of Malaysia's culture and heritage. For years, the government and many other benefactors have done development initiatives to improve the community, yet the results were not successful. Despite countless and various efforts taken for this, the Orang Asli is still considered as the least-developed ethnic compared to the other mainstream people. This paper attempts to give an outlook of the Mah Meri people, which is one of the eighteen (18) Orang Asli ethnics in Malaysia. What is the current trend of the discussion about the Mah Meri people discussed in the publications from 1973-2019 in articles, thesis, journals and proceedings using ERIC, Google Scholar, Scopus, Science Direct and SAGE? Using literature and systematic review, analysis is taken from across various disciplines and fields to provide a critical background and viewpoint on the Mah Meri people, as an indicator for the Orang Asli development. The findings show that there are eight (8) significant themes in the literature review of the Mah Meri people which are belief system, culture and tradition, arts and language, environment, economics and social, tourism and health. From the accumulated and discussed analysis, it is also found that other important aspects of the people like environment, health, and belief system are underrated and least been focused. The findings also show that there are still insufficient details and scholarly reviews, development, and prominent initiatives taken and done on the Mah Meri people. Having said that, more efforts in terms of development initiatives and scholarly reviews have to be done on the Mah Meri people, as well as on the other Orang Asli ethnics respectively, across broader focus and spectrum equally, to ensure the balance community development growth for Orang Asli in Malaysia.
\end{abstract}

Keywords: Orang Asli, Mah Meri, Systematic Review. 


\section{Introduction}

The definitions of indigenous peoples are very subjective. Despite these peoples live on all continents and worldwide, there is no singularly authoritative definition of them under any international law and policy (Indigenous Peoples and the United Nations Human Rights System). Furthermore, it is found that different countries and regions have a different definition for 'Indigenous People' in accordance with their local cultural features, which makes it harder to justify and standardize the definition. According to the United Nation (2003), the fruitful approach is actually about identifying rather than defining indigenous peoples. Regardless of lacking any authoritative definition, attempts are made significantly by scholars, authoritative bodies, and human rights documents to come up with criteria and features on identifying and defining these people.

International Work Group of Indigenous Affairs stated that there are more than 370 million indigenous people spread across 70 countries worldwide and are 5 percent of the global population. However, based on Joona (2012) and Sarivaara, Maatta, and Uusautti (2013) stated that up to 70\% of the total indigenous peoples live in Asia. This statement significantly shows that regions of Asia have the highest number of the total indigenous population worldwide. Based on Shah, Rus, Hussain, and Wahab (2018), the United Nations estimates that there are around 370 million indigenous peoples worldwide, and two thirds out of the portion are in Asia. When it comes to Malaysia, the number of the Orang Asli was estimated to be around 178,197 in the year 2012, which only 1\% from Malaysia's total population, which was 27 million people in the same year (Rosnon, 2016; Shah et al., 2018). In scholars' further discussion, it is also found that out of total Orang Asli's population number, $36.9 \%$ of bases in the remote areas, $62.4 \%$ live in rural areas while only $0.7 \%$ stay in urban areas (Sarjit, Rosnon, \& Redzuan, 2010; Shah et al., 2018).

This paper is an attempt to provide a brief background and the direction of the Mah Meri people's development by identifying the related publications from 1973-2018, analysing the reported data in the relevant publications, and presenting the synthesized results from the relevant publications. The justification of choosing the Mah Meri people is due to the claim that the Mah Meri is the best developed Orang Asli ethnic and model among the other 17 ethnics (Roddin, Yusof, \& Sidi, 2015) . By studying the Mah Meri people, it gives an impression on the indicator for the Orang Asli's development, projecting it as having the privilege by being the best developed Orang Asli ethnic and model.

\section{Orang Asli in Malaysia}

In Malaysia, the Indigenous people are also known as 'Orang Asli' which is a Malay phrase for 'Aborigines' or 'Indigenous' and it is the official term that been used in Malaysia (Rosnon, 2014; Werner, 1997). In fact, Malaysia has many types of indigenous people. They are also not the Malays, but given 'Bumiputera' status. The word 'Bumiputera' is derived from the Sanskrit, which carries the literal meaning of 'son of the land' or 'son of the soil' (Anwar, Wan Hussain@Hashim, Abu Bakar, \& Zakaria, 2013; Rosnon, 2016). However, the term 'Orang Asli' is interchangeable with the term 'Indigenous' or 'Aborigines' that was widely used by British colonial admiration (Gomes, 2004b; Rosnon, 2016). Gomes (2004b) argued further that the exact definition of 'Orang Asli' refers to the indigenous people of Peninsular Malaysia only, who are not Malay-Muslim. Together with indigenous 
peoples of Sabah and Sarawak, which are not called 'Orang Asli,' and the Malays, these peoples are the groups that known and recognized as 'Bumiputera,' which makes up 65.1 percent from the total Malaysia population (see table 1). From the population, the portion the 'Orang Asli', which are the 'Indigenous Peoples' of Peninsular Malaysia, is only from 0.5 to 1 percent, thus making them the minority group of Malaysia's 'Bumiputera'.

Table 1: Categories of Bumiputera

\begin{tabular}{cclll}
\hline Bumiputera of Malaysia & & & \\
\hline$\bullet$ Orang Asli & $\bullet$ & Malays & $\bullet$ & Indigenous \\
& & peoples & $\bullet$ & Indigenous \\
& & Sabah & peoples of \\
& & & Sarawak
\end{tabular}

In peninsular Malaysia, the Orang Asli is mainly separated into three major groups (see table 2), which are the Semang (Negrito), the Senoi, and the Proto Malay (Jabatan Kemajuan Orang Asli, 2016). In total, there are 18 ethnics under these three major tribal groups, and each of the ethnicities has their features such as language and culture that distinguish themselves differently from the others (Masron, Masami, \& Ismail, 2013; Sarjit \& Rosnon, 2018). Masron et al. (2013) made the further claim that in terms of politics and economics, the natives of Sabah and Sarawak are actually in a better position to be compared with the peninsular Orang Asli. When it comes to authoritative and government bodies, the JAKOA, which stands for Jabatan Kemajuan Orang Asli or The Department of Orang Asli Development under the Malaysia Ministry of Rural Development, is the government agency that entrusted to oversee the Orang Asli's affairs (Rosnon \& Abu Talib, 2019; Rosnon \& Sara, 2015).

Table 2: Ethnics of Orang Asli in Peninsular Malaysia

\begin{tabular}{ccc}
\hline The Orang Asli & & \\
\hline Semang (Negrito) & Senoi & Proto Malay \\
\hline$\bullet$ Bateq & $\bullet$ Che Wong & $\bullet$ Jakun \\
- Jahai & $\bullet$ Jahut & $\bullet$ Orang Kanaq \\
- Kensiu & $\bullet$ Mah Meri & $\bullet$ Orang Kuala \\
- Kintak & $\bullet$ Semai & $\bullet$ Orang Seletar \\
- Lanoh & $\bullet$ Semoq Beri & $\bullet$ Semelai \\
$\bullet$ Mendriq & $\bullet$ Temiar & $\bullet$ Temuan \\
\hline
\end{tabular}

Therefore, Orang Asli is used to describe the Aboriginal inhabitants of Peninsular Malaysia who have their own culture, language, faith and lifestyle. The Orang Asli are not a homogeneous ethnic minority (Gomes, 2004a; William-Hunt, 1998). They are a heterogeneous people with socio-cultural differences between each tribe. For example, according to Zalizan, Abdul Razak, and Ahmad Rafaai (2009), Orang Asli community groups in Peninsular Malaysia have their own dialects and languages across their tribes. The Semelai dialect is part of the Austro-Asian language family, while the protoMalay groups, are part of the Austronesian family (Zalizan et al., 2009, pp. 5-6). Orang Asli languages are generally only understood amongst themselves. Modernization has, to some extent, affected the 
lives of indigenous peoples and exposed them to the current development (Rosnon, 2010; Rosnon, Sarjit, Shamsul Azahari, N. Alia Fahada, \& Adam Danial, 2019).

\section{The Mah Meri People}

Mah Meri people is an ethnic under the Senoi group. Almost all of the Mah Meri people live along the coastal region of the west part of Selangor, from Sungai Pelek up to Pulau Carey. Among those regions, Pulau Carey is famous and widely known due to its people for their traditional wood carving skills that also hugely contributed to their tourism and economic sectors (The Star, 2th February 2016). Due to this uniqueness, Werner (1997) preserved and documented the stories of Mah Meri people in his works as well. Besides, the name of the island, which is Pulau Carey may come from the reference to Jugra land and Carey Island Co. Ltd, which was a Scottish-based company that initially started their coconut plantation there in late 1890s (Rahim, 2007). Rahim (2007) further elaborated that there are five main Mah Meri villages on Pulau Carey which are:

Table 3: Mah Meri villages on Pulau Carey

\begin{tabular}{|l|l|l|l|l|}
\hline Mah Meri villages on Pulau Carey \\
\hline $\begin{array}{l}\text { Kampung } \\
\begin{array}{l}\text { Sungai } \\
\text { Bumbun }\end{array}\end{array}$ & $\begin{array}{l}\text { Kampung } \\
\text { Sungai Judah }\end{array}$ & $\begin{array}{l}\text { Kampung } \\
\text { Sungai Kurau }\end{array}$ & $\begin{array}{l}\text { Kampung } \\
\text { Kepau Laut }\end{array}$ & $\begin{array}{l}\text { Kampung } \\
\text { Rambai }\end{array}$ \\
\hline
\end{tabular}

Demographically, Rahim (2007) also made a further explanation of describing that the majority of the Mah Meri people still follow the animistic, superstitious, and naturalistic beliefs which believing in their Moyang, even though a small number have converted to Islam or Christianity. The phrase Moyang means ancestor in Bahasa Malaysia or Malay Language. However, for Mah Meri people, Moyang carries meaning for both their ancestors and other spiritual beings or spirits. They believe that mortals and humans live on the 'Sixth World' or also known as Ti' Enam. Meanwhile, all of the Moyangs or their ancestors, and the good spirits and spiritual beings reside in the 'Seventh World' or 'Overworld' which is known as Ti' Tujoh. Beneath it are the five layers of the Underworld, which the realms that are filled with bad spirits and spiritual beings, hantu or ghosts, diseases and poisonous creatures. The Mah Meri people can be classified as a society that practices animism that believes and depends on the forest and the sea for survival and spiritual purposes (Wardhana, Yuhan, \& Qian, 2014).

It is found that Werner (1997), first volume from the Culture of Healing in Malaysia: Aborigines and Indigenous Peoples Culture of Healing Sub-Series documented the relationship between the wooden carvings of the Mah Meri people with their belief and folklore in hope "...to help the understanding, in other regions of the world, of one part of the great variety of the Malaysian cultural heritage". Rahim (2007) further described how the Mah Meri people actually more familiar conversing in Malay Language nowadays, which resulted from the formal schoolings. However, the mother tongue language, which is Bersisi' language, is still been practiced when conversing among them. 
Based on Werner (1997), the term 'Mah-Meri' carries a literal meaning of 'forest people" The culture of Mah Meri people also seems more of a Proto-Malay group although they are actually under the category of Senoi. Werner also stated that Pulau Carey could be considered as the main focus of the Mah Meri population. Due to their popularity as well, nowadays, the Mah-Meri people at Pulau Carey also have their own Mah-Meri Cultural Village to oversee any tourism affairs and also as a one-stop center for outsiders to reach the community.

Located near to Port Klang and Banting, the Mah Meri people at Pulau Carey are widely and internationally recognized primarily due to their unique wood carvings. Mokhtar and Aini (2014) stated that each of the wood carvings are inspired by dreams had by the carvers. They believe that the spirits, deities, or their ancestors would come into their dreams to tell or warn about something. Thus, the dreams are personified into the carvings as a form of respect. Occasionally, the wooden carvings, which are either wooden statues or wooden masks, would be used in their rituals and prayer or culture ceremonies. However, the carving practices are only be done by menfolk in Kampung Sungai Bumbun and not by other Mah Meri folk from other kampung or villages (Rahim, 2007). Fishing used to be a backbone for their economy but no longer been practiced majorly for now due to high competition with Malay and Chinese fishermen that used more and better boats compared to their small boats (Carey, 1973). Due to this, nowadays, the Mah Meri people are seen to have shifted to the cash economy and trading. Coconut and palms are examples of economic activities that they actively participated. When it comes to the language, the Mah Meri people in Pulau Carey will use Malay language or Bahasa Melayu instead of their native language, which is Besisi language, due to the familiarity and exposure they got from modernization (Majin, Azman, \& Lamun Jailani, 2016).

\section{Methodology}

A systematic review of the topic of literature was undertaken. Based on Kable, Pich, and MaslinProthero (2012); Nightingale (2009); Xiao and Watson (2017), systematic reviews are commonly used when researchers attempt to investigate and discover all data regarding a particular research topic or question so that a fair summary of the literature may be presented. Furthermore, Olckers and Du Plessis (2012) the features of systematic reviews as having the collection of data, data analysis, and data synthesis. In order words, this approach will synthesize all the accumulated data and information to see the connection and the gap within before be presented as 'a fair and impartial summary of the literature' (Nightingale, 2009). This research followed these steps. This research attempted to present the background of the Mah Meri people, however not by merging, analysing, and synthesizing statistic data or studies. Thus, the methodology was qualitative by default. Based on Ross (2010), a sample is a 'subgroup of a population'. Since this research attempted to retrieve all research studies on the Mah Meri people that met the inclusion criteria set, no sampling techniques were applied. There are four steps that need to be carried out in the PRISMA protocol which are identification, screening, eligibility and inclusion. SCOPUS, Science Direct, SAGE, ERIC and Google Scholar were used for the identification process. Three key words are used, which are: Mah Meri, Ma' Betisek and Hma' Meri. It also makes up the inclusive and exclusive criteria to obtain data that truly fulfils the research objective. The criteria used were inclusive and exclusive:

i. Usage of the symbols ",,+- AND, NOT

ii. Limiting the search years from 1973 to 2019 
iii. Findings from journals, theses, proceedings or reports where the search sources are different iv. Use article references to identify other suitable articles

In explaining the method in which data was collected, both the inclusion and exclusion criteria applied, as well as the manner in which the studies were identified, are presented. Four criteria governed study inclusion. The usage of the symbols ",,+- AND, NOT and publication time frame was set as the first criterion. Mah Meri people were formally and knowingly introduced in 1925 by Roland Werner in his published collection Culture of Healing in Malaysia: Culture of Healing of Aborigines and Indigenous Peoples, which then republished again in 1997. As researchers found significant numbers of research and studies about Mah Meri people are in between 1973 and onwards instead, thus the beginning of January 1973 was set as the commencement for the systematic search, while the end date was taken as December 2019, as the search was executed during January 2020. Thus, the time frame was 46 years. The second criterion for inclusion needed the research or studies to have been reported via peer-reviewed or scholarly journals, chapter in edited books, conference papers, and thesis. The proposition behind this second criterion is due to limited studies and data related to the Mah Meri people, when in fact, the people is one of the 17 Orang Asli ethnics in Malaysia. The third criterion and fourth criteria addressed are about the language of the data, as well as the focus addressed. Studies demonstrated in Bahasa Malaysia, or English were included, apart from the focus of the studies that must be about the Mah Meri people too.

\section{Research Findings and Discussion}

A comprehensive electronic search was executed. Mah Meri, Ma' Betisek and Hma' Meri were used as the search term. The number of unique studies found was 27 . The abstract of each of the 27 studies was first studied to confirm the focus on the Mah Meri people. All the articles were then listed on a spreadsheet, and the details captured were (1) year of publication, (2) article title, (3) author(s), (4) type of the data, and (5) identified theme.

Thematic analysis was used to categorize the hypotheses. Based on Fox (2004), thematic analysis is a common approach to data analysis that allows data sources to be examined in terms of their concepts, or themes. The concepts and themes identified then were recorded on the spreadsheet with similar ones being categorized into separate clusters or themes. Lastly, the results section of each of the included data were examined and studied to identify those hypotheses that had been validated. The findings are reported on per identified cluster and theme. The discussion section follows the same approach. The number of hypotheses is presented, per identified cluster and theme in Table 4. 
Table 4: 22 Identified Data about Mah Meri

\begin{tabular}{|c|c|c|c|c|c|c|c|c|}
\hline \multirow{2}{*}{$\begin{array}{l}z \\
\frac{2}{3} \\
\frac{0}{0} \\
\frac{\Phi}{1}\end{array}$} & \multirow[b]{2}{*}{ Title } & \multirow[b]{2}{*}{$\begin{array}{l}\text { Author } \\
\text { (Year) }\end{array}$} & \multicolumn{5}{|c|}{ Type } & \multirow[b]{2}{*}{ Theme } \\
\hline & & & 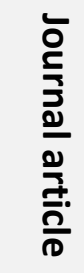 & $\begin{array}{l}\text { 국 } \\
\text { 怘. } \\
\frac{n}{n}\end{array}$ & $\begin{array}{l}\text { प्र } \\
\text { 읏 }\end{array}$ & 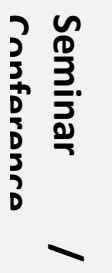 & $\begin{array}{l}D_{0} \\
\text { D } \\
\hat{D} \\
\underline{\nu} \\
\frac{\lambda}{J}\end{array}$ & \\
\hline 1 & $\begin{array}{l}\text { A Brief Account of } \\
\text { The Mah Meri }\end{array}$ & Carey (1973) & / & - & - & - & - & $\begin{array}{l}\text { Culture and } \\
\text { traditions }\end{array}$ \\
\hline 2 & $\begin{array}{l}\text { Ma' Betisek Concept } \\
\text { of Living Things }\end{array}$ & $\begin{array}{l}\text { Wazir-Jahan } \\
\text { (1981) }\end{array}$ & & / & & & & Belief system \\
\hline 3 & Mah Meri & $\begin{array}{l}\text { Werner } \\
(1997)\end{array}$ & - & - & / & - & - & Belief system \\
\hline 4 & $\begin{array}{l}\text { Pantun Suku Kaum } \\
\text { Mah Meri }\end{array}$ & Radzi (2003) & / & - & - & - & - & Arts and language \\
\hline 5 & $\begin{array}{l}\text { Citra Melayu Dalam } \\
\text { Pantun Mah Meri }\end{array}$ & Radzi (2004) & / & - & - & - & - & Arts and language \\
\hline 6 & $\begin{array}{l}\text { Register in Mah } \\
\text { Meri: A preliminary } \\
\text { phonetic analysis }\end{array}$ & $\begin{array}{l}\text { Stevens, } \\
\text { Kruspe, and } \\
\text { Hajek (2006) }\end{array}$ & - & - & - & / & - & Arts and language \\
\hline 7 & $\begin{array}{l}\text { Chita' Hae Culture, } \\
\text { Crafts and Customs } \\
\text { of the Hma' Meri in } \\
\text { Kampung Sungai } \\
\text { Bumbun, } \\
\text { Carey }\end{array}$ & Rahim (2007) & - & - & / & - & - & $\begin{array}{l}\text { Culture } \\
\text { traditions }\end{array}$ \\
\hline 8 & $\begin{array}{l}\text { Breastfeeding } \\
\text { Practices and } \\
\text { Nutritional } \\
\text { Status of Orang Asli } \\
\text { Children } \\
\text { (Temuan and Mah } \\
\text { Meri) }\end{array}$ & $\begin{array}{l}\text { Wan Norlida } \\
\text { et al. (2007) }\end{array}$ & / & - & - & - & - & Health \\
\hline 9 & $\begin{array}{l}\text { Heterogeneity in the } \\
\text { musical acquisition } \\
\text { of Orang Asli } \\
\text { children from the } \\
\text { Mah Meri and Semai } \\
\text { Groups }\end{array}$ & Ching (2009) & / & - & - & - & - & Arts and language \\
\hline 10 & $\begin{array}{l}\text { Mah Meri Onstage: } \\
\text { Negotiating Policies, } \\
\text { Tourism r and }\end{array}$ & Chan (2010) & - & / & - & - & - & $\begin{array}{l}\text { Culture } \\
\text { traditions }\end{array}$ \\
\hline
\end{tabular}


Modernization in

Kampung

Sungai Bumbun,

Carey Island,

Malaysia

11 Penglibatan

Masyarakat

Peribumi

Dalam Isu Berkaitan

Persekitaran:

Tinjauan Terhadap

Suku Mah Meri di

Pulau Carey, Kuala

Langat, Selangor

12 Penglibatan

masyarakat

peribumi dalam isu

berkaitan

persekitaran:

Tinjauan terhadap

suku Mah Meri di

Pulau Carey, Kuala

Langat Selangor

13 Pembinaan

keupayaan dalam Sidi(2013)

Rahman

(2010)

Haliza (2010) / - - - - - Environment

pelancongan Orang

Asli: Satu kajian kes

dalam komuniti Mah

Meri

14 Traditions and

Taboos of The Mah (2013)

Meri

Tribe of Tanjung

Sepat, Banting,

Selangor

15 Culture as An Kunasekaran

Indigenous Tourism Gill, Talib,

Product of Mah Meri and Redzuan

Community in (2013)

Malaysia

Dakwah

Islamiah Mokhtar and -

Kepada Orang Asli di Aini (2014)

Pulau Carey Banting 
Selangor:

Isu, Cabaran dan

Permasalahan

17 Reproduction of South-East Asian (2014)

Culture Artefacts: A

Case

of the Mah Meri

18 A Study of Cultural Identify, Cultural

Heritage and

Tourism

Development in

Mah Meri

Community Cultural

Village,

Carey Island,

Selangor, Malaysia

19 The Role of Women in Sustaining

The Cultural Identity

Wardhana et -

al. (2014)

/ Culture

and traditions of Mah Meri

Influence

That

Roddin et al. /

traditions

and

Success

the (2015)

Mah Meri Tribe in

Tourism Sector

21 Language Vitality

Among the Orang

Asli

Coluzzi, Riget,

- Economics and social

of Malaysia: the case

of the Mah Meri

on Telo' Gunjeng

(Carey Island,

Selangor)

22 Gender and

(2016)

Livehoods: A Case

Lai (2016)

Study

of the Mah Meri and

the Oil Palm

Plantations of Carey

Island 
23 Support for Future Majin et al. - - / - - Economics and

Tourism

(2016)

social

Development,

Quality of Life and

Perceived Impact of

Tourism Industry

Within Indigenous

Community: Mah

Meri of Carey Island.

24 Measuring

Sustainable

Kunasekaran

/

- Tourism

Indigenous

et al. (2017)

Tourism Indicators: A

Case of Mah Meri

Ethnic Group in

Carey Island,

Malaysia

25 Transformation

Value of Mah Mer

Roddin,

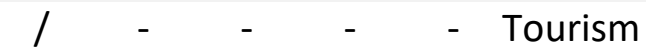

Community

Aboriginal Tourism

in Awang, and

Warman

(2017)

26 The Implications of a

Planned

Aing and

Development on

Consumption

Practices: A Case

Study of an

Orang Asli

Community in

Malaysia

27 The Orang Asli Shah et al. / - - - - Tourism

Profile in Peninsular (2018)

Malaysia:

Background \&

Challenges

$\begin{array}{llllll}\text { Total } & 15 & 3 & 4 & 4 & 1 \\ \text { Grand Total } & 27 & & & & \end{array}$

The number of studies found seemed more saturated and focused in the year 2008 and onwards, where a higher number of quantity and varieties of the type identified. Overall, the studies and data found are also in-between the range of year of 1973 the earliest, and 2018 the latest, with the highest volume of fifteen (15) for journal article type and lowest volume of one (1) for research report type. 
When it comes to the saturation, year of 2010, 2013, 2014, 2016 and 2017 have the highest density with 3 data and information identified for the respective year. From the 27 data and information sorted, the findings and extract of the data are classified and categorized thematically, as presented in Table 5:

Table 5: Number of Identified Themes by Year

\begin{tabular}{|c|c|c|c|c|c|c|c|c|}
\hline \multirow[b]{2}{*}{ Year } & \multicolumn{7}{|l|}{ Themes } & \multirow[b]{2}{*}{$\begin{array}{l}\text { Total } \\
\text { by year }\end{array}$} \\
\hline & $\begin{array}{l}\sum_{n}^{n} \\
\stackrel{D}{D} \\
\stackrel{D}{D} \\
\frac{D}{3}\end{array}$ & 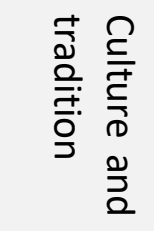 & 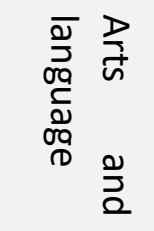 & 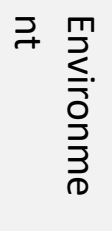 & 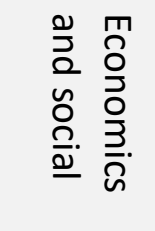 & $\begin{array}{l}\text {-1 } \\
\stackrel{ }{5} \\
\frac{\bar{n}}{3}\end{array}$ & $\begin{array}{l}\frac{T}{D} \\
\frac{D}{\Phi} \\
\frac{ \pm}{5}\end{array}$ & \\
\hline 1973 & 0 & 1 & 0 & 0 & 0 & 0 & 0 & 1 \\
\hline 1981 & 1 & 0 & 0 & 0 & 0 & 0 & 0 & 1 \\
\hline 1997 & 1 & 0 & 0 & 0 & 0 & 0 & 0 & 1 \\
\hline 2003 & 0 & 0 & 1 & 0 & 0 & 0 & 0 & 1 \\
\hline 2004 & 0 & 0 & 1 & 0 & 0 & 0 & 0 & 1 \\
\hline 2006 & 0 & 0 & 1 & 0 & 0 & 0 & 0 & 1 \\
\hline 2007 & 0 & 1 & 0 & 0 & 0 & 0 & 1 & 2 \\
\hline 2009 & 0 & 0 & 1 & 0 & 0 & 0 & 0 & 1 \\
\hline 2010 & 0 & 1 & 0 & 2 & 0 & 0 & 0 & 3 \\
\hline 2013 & 0 & 1 & 0 & 0 & 1 & 1 & 0 & 3 \\
\hline 2014 & 1 & 2 & 0 & 0 & 0 & 0 & 0 & 3 \\
\hline 2015 & 0 & 0 & 0 & 0 & 2 & 0 & 0 & 2 \\
\hline 2016 & 0 & 0 & 1 & 0 & 2 & 0 & 0 & 3 \\
\hline 2017 & 0 & 0 & 0 & 0 & 0 & 3 & 0 & 3 \\
\hline 2018 & 0 & 0 & 0 & 0 & 0 & 1 & 0 & 1 \\
\hline $\begin{array}{l}\text { Total by } \\
\text { theme }\end{array}$ & 3 & 6 & 5 & 2 & 5 & 5 & 1 & 27 \\
\hline
\end{tabular}


There are seven identified themes, which are (1) belief system, (2) culture and tradition, (3) art and language, (4) environment, (5) economics and social, (6) tourism, and (7) health. The findings found are various studies and research been done from many perspectives and spectrums. From the table 5 , the distribution of the data found seems more concentrated on the theme and area of culture and tradition as the highest with the total number of sixth (6), following by economics and social with five (5), tourism with five (5), art and language with five (5), belief system with three (3), environment with two (2) and health with one (1). Yearly, year of 2010, 2013, 2014, 2016 and 2017 have the highest number of studies with three (3) correspondingly. These backgrounds and literature surveys worth to be addressed for a better understanding of the Mah Meri people's affairs, as well as to identify the scholarly gap that potentially can be fulfilled in the future. Thus, this paper describes an overall outlook, perspective, and narrative found on the Mah Meri people.

\section{Themes and Issues among Mah Meri People \\ Belief System}

It is found that the earliest form of documentation about the Mah Meri people was done ad captured in Werner's Mah Meri. The work was published in 1997 and considered as the earliest form of documentation that captures the history and stories of Mah Meri people. However, the focus of the discussion seemed saturated more on the belief of the people, which are their oral tradition and folklore, mainly about the deities and spirits. As been mentioned earlier, there is a strong connection between Mah Meri's belief with their wooden carvings and sculptures produced by the local carvers. The narration of the work is descriptive, describing the stories behind the carvings from the perspective of history, local folklore, and belief. Thus, this work is considered as holistic descriptive documentation about the Mah Meri people before the subject is studied further by future researchers.

Other researches were also attempted to investigate and study the Mah Meri people from belief perspective. Another example of a study for this cluster is the study on the issues and challenges in spreading Islam among the Mah Meri people (Mokhtar \& Aini, 2014). The researchers stated that Islam is still hard to be accepted by the Mah Meri people as the contents are not aligned with the people's interest. It is found that only $8 \%$ of the whole Mah Meri people at Pulau Carey have already been embraced, Islam. Been said so; it is believed that strong attachment with their own ancestor belief is one of the reasons for poor acceptance of Islam. Furthermore, the strong negative connotation of Islam with the Malay stereotype could also contribute to the phenomenon. However, it is found that a small number of Mah Meri people did embrace Islam in their lives due to marriage with Malay-Muslim partner. However, this finding and thesis are conflicting with the statement that the Mah Meri people have a strong attachment with their ancestor belief. If only due to marriage could change the belief of the people, the earlier stated thesis is then debatable and open for further discussion that can be explored by future researchers.

As one of the 18 Orang Asli ethnics in Malaysia, the superstitious belief is already a part of their identity as it is deeply rooted since their late ancestors. This belief does not only affect the way they live but also on how they perceive the world around them, be it culturally and historically. The belief system plays a very prominent role in shaping almost all aspects of the community's life. Based on Wardhana et al. (2014), the people believe that all beings and things like humans, animals, plants, 
and inanimate objects have their own deity and spirit. Any form of offence will cause and bring curses, illnesses, natural disasters, misfortunes, or bad lucks. Another example of the belief is that the people of Mah Meri believed that their ancestors 'cursed' the river junction to expand the new channel further. The riverbanks then began to erode, and the channel deepened, which is Sungai Langat (Rahim, 2007). This is one of the other many stories that described not only their origin and history but also covered almost all aspect of Mah Meri people.

The Mah Meri people also firmly believe that any unusual geographic or natural features such as large rocks or natural forces like lightning are all resided by spirits or superstitious beings (Carey, 1973). Still, they do believe in the existence of God that is known as Tuhan that created the world and all beings. However, He has very little interest in men's affairs. Hence why it is only once a year, the Mah Meri people would celebrate Ari' Muyang's or 'Ancestor's Day Celebration' in paying respects and celebrating the ancestors and the spirits instead of the Tuhan. These superstitious beliefs and practices become their important points when they face any crisis in life, especially affairs that are related to birth, marriage, divorce, or death.

As pointed out by Rahim (2007), only a small percentage and numbers of wooden carvings will be housed in their sacred shrines for ritual purposes. Nowadays, most of the wooden carvings have been produced only for the sake of continuing and preserving their identities and traditions while also trading the carvings to the outsiders to generate their side income. Wardhana et al. (2014) claimed that those wooden carvings produced, which are the statues and the masks, are a form of personification of the people's lives, believes, legends and myths. These features are also acknowledged by UNESCO or The United Nations Educational, Scientific, and Cultural Organization as part of the world's heritage that should be preserved.

Drawing from the existing and current Literature Review, we found that there is a potential gap in the affair of Mah Meri people. It is interesting when seeing the amount of research and studies been done on the Mah Meri people as they are also praised and commended as the best model of Orang Asli today (Roddin et al., 2015). Furthermore, any relevant studies to investigate the connection and relationship between the Mah Meri people's beliefs and the aspects of their lives could provide the better and latest understanding and insight about the state of their belief, which also shapes and contributes to their life values. This statement could be an important indicator not only to the Mah Meri people themselves but also potentially to be applied to another Orang Asli ethnic in Malaysia.

\section{Culture and Tradition}

Carey (1973) also documented briefly in his article about the Mah Meri's origin, history, economy, social structure, and beliefs. Interestingly, Carey's writing is found as one of the earliest attempts of documenting the Mah Meri people, covering the area of origin, economy, and social structure and belief system. Since the documentation is more than forty years, any similar attempt could potentially be made now as a development indicator in understanding the changes that occurred throughout the time. Thus, this scholarly comparison in this area could give a better perspective on the evolution of the Mah Meri people, concerning the same and similar aspects. 
Pang et al. (2014) discussed the replication of the Mah Meri's cultural artefacts which are the wooden masks by using 3D scanning and printing method, including the justifications and the necessary steps. The researchers supported the importance of expanding the perseverance of the Mah Meri cultural artifacts by claiming that these artifacts carry stories and values which are meant to be passed to the future generation. With the help of technology inventions like 3D scanning, the artifacts are potentially to be preserved better. Nevertheless, it is also undeniable that the original artifacts are better to be preserved than the 3D scanning versions as the authenticity of the works is almost impossible to be transferred or duplicated in such 3D scanning method. Yet, it is still a good initiative as the resources or the artifacts are limited and valuable.

There are quite a number of documentations found in regards to preserve the stories of the Mah Meri people. Chita' Hae's Culture, Crafts and Customs of the Hma' Meri in Kampung Sungai Bumbon, Pulau Carey (Rahim, 2007) is an example of books that described the background, history, and culture of the Mah Meri people in brief. Interestingly, it is found on how the author able to highlight the issues on the tradition, such as the worriedness of the elders towards the young generation in losing their identity due to modernization. Rahim (2007) also stressed the possibility of unable to continue the cultural practices such as the wooden carvings and origami due to the plantation occurred in their settlements and community. On the other side, the relationship between the plantations with the local people is potentially to be explored and studied in the future, which is to study and justify the benefits from and for both parties, be it the Mah Meri people, or the plantations.

Rahim (2007) also claimed that there are some correlations between faith, belief, and spirituality with the products of arts, just how the wooden carvings produced by the Mah Meri people. These productions are a form of reflection and personification from their belief system, and their folklore. For these people, the wooden carvings are also a form of spiritual communication, which is commonly can be seen and found in other indigenous communities globally. However, in Malaysia, only 2 out of 18 ethnicities are found to have this feature, which is the Mah Meri people in Selangor, and Jah Hut people in Pahang. Nevertheless, the production of the carvings is also having challenges in sustaining within the community because the young generation is not keen on this ancestor knowledge anymore. Thus, this phenomenon is open for further interpretation that, if it is regarded as a form of spiritual communication, does it mean that having less interest and production among the younger generation could be a current indicator for their spirituality in this modernization world?

On the other side, Azyantee (2013) validated and verified the relevance of the taboo practices among Mah Meri people. As described by Azyantee (2013), Yok (2006) also have done the prior descriptive documentation on the taboo practices have done the prior descriptive documentation on the taboo practices, hence why his article titled Traditions and Taboos of The Mah Meri Tribe of Tanjung Sepat, Banting, Selangor specifically focused on the taboo practices supported that the practices are still relevant within the community. We found that similar research also can be done by focusing on the Mah Meri people at Pulau Carey instead by seeing the comparison between these two geographically different settlements. From the musicology perspective, a PhD thesis in Music by Chan (2010) validated the influence of the Mah Meri folklore, myth and belief towards their music, songs, lyrics, and all musical practices. Interestingly, this research analysed and focused on a holistic perceptive in 
the musicology of the Mah Meri people. Having said so, it also would be significantly beneficial if similar interests been analysed from different spectrums like anthropology and sociology point of view, to study more the influence of the Mah Meri folklore, myth and belief towards the other community capitals.

Wardhana et al. (2014) investigated further on the relationship between the Mah Meri's cultural identity, cultural heritage, and tourism development. The researchers found that there are prominent cultural features and practices of the Mah Meri that significantly affected the success of the tourism industry, which are the wood carvings, performing arts and masks, and the local rituals along with the celebrations (Wardhana et al., 2014). These aspects work together with the initiatives by the local authorities such as the tourism campaign and the development of the infrastructure like the Mah Meri Cultural Village. By quoiting Miller (1985), the researchers claimed that the right timing that matches the increment of demand in the cultural tourism industry had benefited the Mah Meri people because consumers prefer to invest more in the unique-based experience of tourism. This is due to the reason that these physical objects are a form of personification that embodied people's lives, experiences, and values. In general, the researchers concluded that the tourism industry has the potential to develop the economic, social, cultural, and political aspects of the tourism subjects, which are the communities. Thus, all the features of a community, regardless of the area, shall be maintained and preserved.

\section{Arts and Language}

From the perspective of arts and language, Radzi (2003); Karageorgopoulos (2014) studied and documented the pantun or a form of poetic verses of the Mah Meri people in the descriptive documentation. Radzi (2003) also studied the relationship on the Malay influences inside Mah Meri pantun or a form of poetic verses that are found rhymed. There also some attempts to investigate the linguistic side of the Mah Meri language like Stevens et al. (2006), where the researchers analysed the phonetic features of the language. Coluzzi et al. (2016) conducted a similar study on understanding language vitality among the Mah Meri people. Language does play a vital role in community and culture vitality, and it is strongly suggested to conduct more similar research in this particular area to indicate the level of authenticity and originality of the people, by using their language as an indicator and measurement.

\section{Environment}

On the other side, Rahman (2010) sought further on the Mah Meri people and their involvement and participation in environmental issues, yet the findings have shown that the level and involvement and participation is still low. The findings suggested that it is either due to lack of awareness and education about an environmental issue, or the community members have limited power, authority, and voice in this topic. Been said so, the limitation in having power, authority, and voice is potentially to be explored by future researches to figure out the factors of occurrence, as well as the effects of it to the community itself and other parties. 


\section{Economics and Social}

Lai (2016) attempted to understand the livelihood changes that occurred in the Mah Meri people based on gender. From the dependency on the forest resources shifted to the nearby large-scale oil palm holdings, the finding suggested that the male folks are empowered better while the female folks became disempowered instead. The plantations offered jobs to the male folks, which significantly increase the gap of economic empowerment between male and female folks. Nevertheless, this finding also proved that modern economics brought significant positive changes among the people. We found that this thesis is potentially to be studied further and broader by future researchers. On the other side, Kunasekaran et al. (2013); Roddin and Sidi (2013) attempted a study and research in discussing the development and sustainability in the Orang Asli tourism, mainly focused on the Mah Meri people using a sustainability barometer. It argued how the Orang Asli could potentially be utilized to sustain their economy, mainly by hitting the tourism industry and sector.

Two years later, Harun (2015) made an argument in her research findings by quoting the Mah Meri women do play an essential role in the society, culturally and economically. It is found that the Mah Meri women are among those who are vigorously participated in the Mah Meri indigenous tourism because they are the one that produces the handicrafts, thus ensuring the preservation and protection of their cultural heritage and crafts from being disappeared in modernization. However, if it to be compared with the male folks' empowerment in oil palm plantations, the number for female folks' empowerment in the tourism industry is significantly lower. This suggests that the oil palm plantation industry itself is more effective when it comes to community development and empowerment, but again, what are the factors and limitations of it? An excellent projection on this area is potentially to be investigated as well to provide better literature review and insight on the Orang Asli development in Malaysia.

Moreover, Ting and Abella (2017) attempted to see how the planned development initiatives affected the consumption practices and the way of life of the Mah Meri people, which could be negative or positive. Similar study also has been done a year before by Majin et al. (2016) when the researchers studied on the further and deeper impacts of tourism industry within indigenous community, specifically drawn the Mah Meri people as the research subject. The finding shows that there are positive impacts that occurred to the Mah Meri people in terms of their Quality of Life, which is also due to a factor of Mah Meri people's positive attitude and support for tourism development initiatives.

Level of openness is among the factors that hold the Orang Asli community back from receiving and embracing this kind of approach, just like the Batek ethnicity that sees tourism approaches as a form of privacy invasion. However, the Mah Meri people accepted the proposed development plans, and eventually, they reaped what they sowed, as their socio-economic has been shown to have some significant improvements. This is regarded as an internal factor. Roddin et al. (2015) also cited the roles of external parties that served as the external factors to their tourism industry success, which are the roles played by the JAKOA and the NGOs. In fact, several community centres, kiosks, workshops, and facilities have been designed and built by these benefactors to support the Mah Meri people. Nevertheless, the scholars suggested that the real core of the issue is the Mah Meri' level of 
education, which is still significantly inadequate, just like the other ethnics of the Orang Asli. As long as this concern has not been appropriately tackled by the benefactors, any other development plans, as well as the tourism industry development approaches, would not be sustainable enough for a long haul to develop the community's socio-economy holistically.

\section{Tourism}

In a further similar discussion, Kunasekaran et al. (2017) made measurement and validation on the indigenous tourism sustainability of the Mah Meri people. Mah Meri people, in fact, is an example of how the people utilized and commercialized their carving products to the outside world. The finding shows that in general, the Mah Meri people actually support the local tourism industry collectively for the benefit of all in return, even not all are actively and directly involved with the local tourism sector. The issue found is about the gap between the high interests of people with low participation in tourism activities. This gap is potentially to be studied further to analyse the rate and factors of the drop-off and the reasons why these interested people are not converting into the participation and execution part of the tourism activities.

In additional, Kunasekaran et al. (2017) also cited Dernoi (1983) by claiming that tourism allows the indigenous community not only to enjoy the benefit in the perspective of economics but also ensuring the younger generations to be sustained and maintained with the indigenous knowledge, thus preserving the culture and traditions of the people. Furthermore, sustaining the development of tourism would attract potential stakeholders and benefactors like entrepreneurs, NGOs, government agencies, and academic researchers. To ensure this, their skills and indigenous knowledge are very prominent in developing the tourism industry. In return, this would benefit the people in return, like increasing the employments, providing mediums and platforms for businesses, investments, and entrepreneurship that involving both government and private sectors, which eventually would bring in money from the outsiders. On the aspect of personal empowerment, the tourism industry also allows the community to be exposed and be learning about the outside world and cultures, which would make them have better, exciting lifestyles.

In general, the community does receive benefits from the tourism sector, which is also due to the main attraction and feature of the people, which are their sacred wooden carvings and artifacts. Roddin et al. (2015) discussed the factors that affected this. It is undeniable that the education level among Mah Meri people at the moment is still considered inadequate; thus, it is accepted that indigenous development is the fastest and simplest strategic plan compared to other development models. However, tourism approaches that aimed to improve the indigenous community sustainably might only be practical until certain limitations, because it does not hit the cause and root of the phenomenon, and also due to some other challenges. Thus, we found this is another interesting potential gap and issue that can be addressed and investigated further. Two years later, in understanding the tourism phenomenon revolving the Mah Meri people further, Roddin et al. (2017) deeper the transformation value of Mah Meri people relating with the tourism itself, and the finding shows that in general, tourism industry still brings benefits to the people. However, as discussed by the researchers, education is still a vital initiative in developing the community for the long term. 
Summing up the past reviews that have been done on Mah Meri people, Shah et al. (2018) made a summarized review on background and challenges for the Orang Asli in Peninsular Malaysia, by citing the Mah Meri people as one of the examples. The researchers mentioned a similar pattern in highlighting the importance of sustaining indigenous tourism among the Orang Asli, as these people are the major portion when it comes to the national poverty data (Shah et al., 2018). Shah et al. (2018) also mentioned by crediting the government for planning and executing various programs and initiatives like economic programs, relocation planning, and other initiatives aimed and designed for improvising human capital development, specifically for the Orang Asli people. However, the results were not really successful. Thus, despite the fact that significant numbers of development initiatives been taken and executed to develop the community were to no avail, future researches could investigate deeper the issues within the scope that challenged the effectiveness of the development initiatives.

\section{Health}

In 2007, there was research attempted to investigate the relationship between the breastfeeding practices and nutritional status related to the Mah Meri people in Breastfeeding Practices and Nutritional Status of Orang Asli Children (Temuan and Meh Meri) in Sepang District and Carey Island (Wan Norlida et al., 2007). The researchers discussed further the argument by studying the perceptions and knowledge of the mothers on child health and nutrition. Researchers claimed that there are insufficient health and nutritional published data on Orang Asli children in Malaysia; thus, the research attempted to expand the literature review on this area. The finding shows that the children of these selected Orang Asli ethnics are undernutrition due to awareness and knowledge about the importance of correct breastfeeding practices, where the mean period of breastfeeding is 12 months, instead of a minimum of twenty-four (24) months as recommended by World Health Organisation. Most of the children are also found underweight, due to poor feeding practices among the community. There are few factors contributed to this finding, and each of the factors is related to each other, such as low social and economic status, lack of awareness, limited resources among the society. Nevertheless, this study is a good start for future researches to explore more on identifying and studying deeper the issues in the perspective of health sciences and development, so that any appropriate approaches can be suggested to overcome the issues.

\section{Conclusion}

It is recommended for future studies and efforts to explore those themes that have a lesser number of research and studies done so that better and holistic literature and insight about the Mah Meri people can be presented and provided. From the findings, there are three (3) themes with the least total number of studies, which are environment, health, and belief system. Focus and attention should be given more to further studying and exploring these areas and clusters. In fact, when it comes to indigenous studies, these three particular themes are very significant corresponding to them. Nevertheless, the rest of the themes are also can be equally given attention by future researchers for better studies as well. Based on the past literature surveys, it is found and concluded that the Mah Meri people and community is no longer a new subject in the academic world. Various studies have been done on the Mah Meri people from various and different fields like medical and sciences, linguistic, and social sciences. Most of this research concerned with the issues faced by the 
people, as well as on the prominent aspects and futures of Mah Meri people, which are their folklore, mythology, arts, and cultural practices. Little focus has been given on the health sciences perspective, which is vital to the community, regard them as the minority, which definitely needs better focus in this area.

However, the big portion of the literature surveys is found focusing on the indigenous tourism of the Mah Meri people. The focus is also inter-related with the spectrum of arts and language of the people as the discussions argued the relationship between these features with the people's indigenous tourism. It also can be concluded that without strong education within the community, indigenous tourism itself has its own limitations. Thus, it is strongly suggested for future benefactors to focus on the people's education for a long-term development benefit. Nevertheless, an overall outlook on the other perspectives of the Mah Meri people also have been discussed in this paper, which is vitally to be highlighted as they do contribute to the development of the community, respectively. As mentioned earlier, the Mah Meri people is regarded as the best ethnic among the 18 Orang Asli ethnicities when it comes to the development perspective. Thus, this outlook allows future researches to indicate where are the potential future directions of the people from the gaps found, and studies been done on the people. Nevertheless, any executed plans and initiatives that bring benefits may be followed by other ethnics as well. Furthermore, this outlook also gives a better picture and understanding of the best scenario and projection about the Orang Asli development Malaysia, which also allows future researchers to understand the phenomenon better, and hopefully could catalyst the research and plans regarding the development better, which eventually could benefit the community back more effectively.

\section{Corresponding Author}

Dr. Mohd Roslan Rosnon

Institute for Social Science Studies, Universiti Putra Malaysia, 43400 UPM Serdang roslan_rosnon@upm.edu.my

\section{References}

Anwar, O. M., Wan Hussain@Hashim, W. A. F., Abu Bakar, J., \& Zakaria, Z. (2013). Legitimacy of the Malays as the Sons of the Soil. Journal of Asian Social Science, 9(1): 74-84.

Azyantee, M. Z. (2013). Traditions and Taboos of The Mah Meri Tribe of Tanjung Sepat, Banting, Selangor. Jurnal Antarabangsa Dunia Melayu, 6(2): 155-169.

Carey, I. (1973). A Brief Account of The Mah Meri. Journal of the Malaysian Branch of the Royal Asiatic Society, 46(2): 185-194.

Chan, C. S. C. (2010). Mah Meri Onstage: Negotiating Policies, Tourism and Modernization In Kampung Sungai Bumbun, Carey Island, Malaysia (PhD), University of Hawai'i Manoa.

Ching, C. C. S. (2009). Heterogeneity in the musical acquisition of Orang Asli children from the Mah Meri and Semai Groups. Malaysian Music Journal, 1(2): 1-19. 
Coluzzi, P., Riget, P. N., \& Xiaomei, W. (2016). Language vitality among the Orang Asli of Malaysia: the case of the Mah Meri on Telo' Gunjeng (Carey Island, Selangor). International Journal of the Sociology of Language, 2017(244): 137-161.

Dernoi, L. A. (1983). Farm tourism in Europe. Tourism Management, 4(3): 155-166.

Fox, N. J. (2004). Qualitative data analysis: HAR6010 (Taught unit from MSc in Health and Social Care Research). Sheffield: University of Sheffield.

Gomes, A. G. (2004a). Looking for Money: Capitalism and Modernity in an Orang Asli Village. Melbourne: COAC, Kuala Lumpur and Trans Pacific Press.

Gomes, A. G. (2004b). The Orang Asli of Malaysia. Netherlands: IIAS News Letter.

Haliza, A. R. (2010). Penglibatan masyarakat peribumi dalam isu berkaitan persekitaran: tinjauan terhadap suku Mah Meri di Pulau Carey, Kuala Langat Selangor. Kemanusiaan, 17: 111-134.

Harun, N. R. (2015). The Role of Women in Sustaining The Cultural Identity of Mah Meri (Master), Universiti Teknologi Mara, Malaysia.

Jabatan Kemajuan Orang Asli. (2016). Data Maklumat Asas Orang Asli 2016. Kuala Lumpur: Jabatan Kemajuan Orang Asli Malaysia.

Joona, T. (2012). ILO Convention No. 169 in a Nordic Context with Comparative Analysis: An Interdisciplinary Approach. Rovaniemi: Lapland University Press.

Karageorgopoulos, C. (2014). Information Handling Manner As Main Unifying Factor In Community Building. Multilingual Academic Journal of Education and Social Sciences, 2(2), 92-106.

Kable, A. K., Pich, J., \& Maslin-Prothero, S. E. (2012). A structured approach to documenting a search strategy for publication: A 12 step guideline for authors. Nurse Education Today, 32(8): 878886.

Kunasekaran, P., Gill, S., Ramachandran, S., Shuib, A., Baum, T., \& Afandi, S. H. M. (2017). Measuring Sustainable Indigenous Tourism Indicators: A Case of Mah Meri Ethnic Group in Carey Island, Malaysia. Sustainability, 9(7): 1256.

Kunasekaran, P., Gill, S., Talib, A., \& Redzuan, M. (2013). Culture as an indigenous tourism product of Mah Meri community in Malaysia. Life Science Journal, 10(3): 1600-1604.

Lai, W. T. (2016). Gender and Livelihoods: A Case Study of the Mah Meri and the Oil Palm Plantations of Carey Island. Asian Journal of Women's Studies, 17(2): 66-95.

Majin, J. J., Azman, I., \& Jailani, L. F. (2016). Support for Future Tourism Development, Quality of Life and Perceived Impacts of Tourism Industry Within Indigenous Community: Mah Meri of Carey Island, Malaysia. In M. Abdullah, W. Yahya, N. Ramli, S. Mohamed, \& B. Ahmad (Eds.), Regional Conference on Science, Technology and Social Sciences (RCSTSS 2014) (pp. 1063-1073). Singapore: Springer.

Masron, T., Masami, F., \& Ismail, N. (2013). Orang Asli in Peninsular Malaysia: Population, Spatial Distribution and Socio-Economic Condition. Journal of Ritsumeikan Social Sciences and Humanities, 6: 75-115.

Miller, M. (1985). The report of the Committee of Review of Aboriginal Employment and Training Programs. Canberra: Australian Government Publishing Service.

Mokhtar, H., \& Aini, Z. (2014). Dakwah Islamiah Kepada Orang Asli di Pulau Carey Banting Selangor: Isu, Cabaran dan Permasalahan. In A. Puteh \& A. I. Mokhtar (Eds.), Seminar Antarabangsa Dakwah \& Etnik 2014: Da'wah \& Ethnicity: Multidiscplinary Perspective. Bangi: Pusat Kajian Dakwah Orang Asli dan Pribumi UKM. 
Nightingale, A. (2009). A guide to systematic literature reviews. Surgery, 27(9): 381-384.

Olckers, C., \& Du Plessis, Y. (2012). The role of psychological ownership in retaining talent: A systematic literature review. SA Journal of Human Resource Management, 10(2): 1-18.

Pang, C. H., Thwaites, H., Pauzi, M. A. M., Khong, C. W., Noor, F. N. M., \& Zainalee, M. A. M. D. H. (2014). Reproduction of South-East Asian Culture Artefcts: A Case of the Mah Meri 2014 International Conference on Virtual Systems \& Multimedia (VSMM) (pp. 261-266). Hong Kong: IEEE.

Radzi, S. B. M. (2003). Pantun Suku Kaum Mah Meri. Akademika, 62(3): 41-57.

Radzi, S. B. M. (2004). Citra Melayu dalam Pantun Mah Meri Jurnal Peradaban Melayu, 2: 114-137.

Rahim, R. (2007). Chita' Hae Culture, Crafts and Customs of the Hma' Meri in Kampung Sungai Bumbon, Pulau Carey. Subang Jaya: Center For Orang Asli Concerns.

Rahman, H. A. (2010). Penglibatan Masyarakat Peribumi Dalam Isu Berkaitan Persekitaran: Tinjauan Terhadap Suku Mah Meri Di Pulau Carey, Kuala Langat, Selangor. . The Asian Journal of Humanities, 17: 111-134.

Roddin, R., \& Sidi, N. S. S. (2013). Pembinaan keupayaan dalam pelancongan Orang Asli: satu kajian kes dalam komuniti Mah Meri. Paper presented at the Proceeding of the International Conference on Social Science Research, Pulau Pinang.

Roddin, R., Yusof, Y., Awang, H., \& Warman, S. (2017). Transformation Value of Mah Meri Community in Aboriginal Tourism. Journal of Global Business and Social Entrepreneurship (GBSE), 3(6): 4757.

Roddin, R., Yusof, Y., \& Sidi, N. S. S. (2015). Factors That Influence The Success of Mah Meri Tribe In Tourism Sector. Procedia Social and Behavioral Sciences, 204: 335-342.

Rosnon, M. R. (2010). Penggunaan Barangan dan Perkhidmatan Sebagai Petunjuk Pembangunan Komuniti Orang Asli Di Daerah Jelebu, Negeri Sembilan. (Master Master), Universiti Putra Malaysia, Serdang.

Rosnon, M. R. (2014). Challenges on the Orang Asli's Rights in Mainstream Education in Malaysia: An Overview. Malaysian Journal on Human Rights, 57-72.

Rosnon, M. R. (2016). Indigenous education policies in Malaysia and Australia: a study of the recognition of indigenous rights and self-determination. (PhD), University of South Australia, Adelaide South Australia.

Rosnon, M. R., \& Abu Talib, M. (2019). Indigenous Education Rights: The Malaysian Case. International Journal of Academic Research in Business and Social Sciences, 9(10): 149-167.

Rosnon, M. R., \& Sara, C. (2015). Discourse Of Indigenous Education Policy: The Malaysian Case. International Journal for Innovation Education and Research, 3(10): 126-140.

Ross, S. M. (2010). Introductory statistics. Burlington: Elsevier.

Sarivaara, E., Maatta, K., \& Uusautti, S. (2013). Who is Indigenous? Definitions of Indigeneity. European Scientific Journal, 1: 369-378.

Sarjit, S. G., \& Rosnon, M. R. (2018). Pembangunan kontemporari Orang Asli. Serdang: Penerbit Universiti Putra Malaysia.

Sarjit, S. G., Rosnon, M. R., \& Redzuan, M. (2010). Acculturation of Consumerism Among The Orang Asli Community in Jelebu, Negeri Sembilan. Petanika Journal Social Sciences and Humanities, 18(2): 321-331. 
Shah, N. M., Rus, R. C., Hussain, M. A. M., \& Wahab, N. (2018). The Orang Asli Profile in Peninsular Malaysia: Background \& Challenges. International Journal of Academic Research In Business \& Social Sciences, 8(7): 1157-1164.

Stevens, Kruspe, \& Hajek. (2006). Register in Mah Meri: A preliminary Phonetic Analysis. Germany: Dresden.

The Star. (2016). Mah Meri Carvers Do It With Spirit. The Star. Retrieved from https://www.thestar.com.my/lifestyle/star2.com-video/2016/02/02/mah-meri-carvers-do-itwith-spirit.

Ting, D. H., \& Abella, M. S. (2017). The Implications of a Planned Development on Consumption Practices: a Case Study of an Orang Asli Community in Malaysia. In A. Gneezy, V. Griskevicius, \& P. Williams (Eds.), Association for Consumer Research (Vol. 45, pp. 914-915). Duluth: Labovitz School of Business \& Economics, University of Minnesota.

United Nation. (2003). The UN Permanent Forum on Indigenous Issues Report of the second Session E/2003/43,E/C.19/2003/22 (UNESCO Ed.). New York: Economic and Social Council Resolution.

Wan Norlida, W. N., Zalilah, M. S., Khor, G. L., Ng, W. C., Mirnalini, K., Nawalyah, A. G., \& Hejar, A. R. (2007). Breastfeeding Practices and Nutritional Status of Orang Asli Children (Temuan and Meh Meri) in Sepang District and Carey Island. Malaysian Journal of Medicine and Health Sciences, 3(2): 1-15.

Wardhana, F. S., Yuhan, X., \& Qian, C. (2014). A Study of Cultural Identity, Cultural Heritage and Tourism Development in Mah Meri Community Cultural Village, Carey Island, Selangor, Malaysia.

Wazir-Jahan, B. K. (1981). Ma' Betisek Concept of Living Things. (PhD), London School of Economics, New Jersey.

Werner, R. (1997). Mah Meri. Kuala Lumpur: University of Malaya Press.

William-Hunt, A. (1998). Orang Asli dan cabaran pembangunan. In M. N. Hassan (Ed.), Warga Pribumi Menghadapi Cabaran Pembangunan (pp. 76-87). UKM: Jabatan Sosiologi dan Antropologi.

Xiao, Y., \& Watson, M. (2017). Guidance on Conducting a Systematic Literature Review. Journal of Planning Education and Research, 39(1): 93-112.

Yok, C. K. (2006). Etnografi Kampung Bukt Bangkong, Sepang. In O. Asmah (Ed.), Bahasa Mah Meri (pp. 11-34). Kuala Lumpur: Universiti Malaya.

Zalizan, M. J., Abdul Razak, A., \& Rafaai, A. (2009). Perspektif Historiografi Masyarakat Orang Asli di Semenanjung Malaysia. In A. Abdul Razak \& M. J. Zalizan (Eds.), Masyarakat Orang Asli: Perspektif pendidikan dan sosiobudaya. (pp. 1-18). Bangi: UKM. 